\title{
ASSESSING ECOTOURISM POTENTIAL OF THE FRUŠKA GORA N.P. AND THE IMPACTS ON RURAL DEVELOPMENT
}

\author{
Sonja Braunovićl ; Filip Jovanović
}

\begin{abstract}
The aim of the paper is to identify and assess the factors for the development of ecotourism in the Fruška Gora National Park and to predict possible benefits for strengthening the rural economy of the area. Literature and field research was done to gather information related to geographical location, biodiversity of habitats and species, elements of cultural heritage and infrastructure of the area, as well as demographic and socio-economic status of the local community. To evaluate constraints and future possibilities of ecotourism in the area, SWOT and PESTEL analyses were used. It was found that the convenient location, substantial wildlife resources, abundance in water and geological elements, and the richness of the cultural-historical monuments are an important touristic potential of the area. The main conclusion of the work is that the development of sustainable ecotourism should create the necessary conditions for the rural development, if strategic and financial support is provided.
\end{abstract}

Key Words: ecotourism, rural development, protected areas, Fruška Gora National Park, Serbia

JEL classification: $O 18, Q 57, Z 32$

\section{Introduction}

At the end of the last century, tourism became one of the world's largest economies (Sathe \& Manepatil, 2013). As tourism has a great role in the world economy, in the framework of sustainable development there is the concept of sustainable tourism which has minimal impact on the environment and culture of the local population, and, on the other hand,

\footnotetext{
${ }^{1}$ Sonja Braunović, PhD, Research Associate, Institute of Forestry, 3 Kneza Višeslava, 11000 Belgrade, Serbia, +381628838014, e-mail: sonjabraunovic@yahoo.com

${ }^{2}$ Filip Jovanović, PhD, Research Associate, Institute of Forestry, 3 Kneza Višeslava, 11000 Belgrade, Serbia, +381628838006, e-mail: filip.a.jovanovic@gmail.com
} 
ensures economic stability and affects the protection of tourist resources. In the framework of sustainable tourism, several types of tourism are developed of which the most developed are ecotourism, rural tourism, cultural tourism, adventure tourism, etc. (Gajić \& Cvetanović, 2015). Ecotourism is defined as environmentally responsible travel to natural areas, in order to enjoy and appreciate nature (and cultural features) that promote conservation, have a low visitor impact and provide for beneficially active socio-economic involvement of local peoples (IUCN, 2020). While conventional tourism involves activities that are often harmful to the local environment, ecotourism is bounded to be sustainable. This sustainability incorporates environmental, experimental, sociocultural and economic dimensions (Sathe \& Manepatil, 2013).

Protected areas are a very important potential for the development of ecotourism (Počuča \& Matijašević-Obradović, 2017) which is considered to be a great economic development opportunity for the Western Balkans and Serbia. Serbia intends to get about $12 \%$ of its territory covered with some level of protection, which is great development potential (Lutovac \& Đuričić, 2014). The Fruška Gora National Park is one of five national parks in the Republic of Serbia. Diverse features of the area have national, regional and international significance. Based on these features, two primary functions of the park management are to conserve the biological diversity and protect the landscape with its unique ecosystems.

However, the growing fragmentation of the landscape due to forest exploitation and poverty of the people resided in the vicinity of the park are the most prominent facts that threatened the area. One of the critical solutions which should raise awareness among people about natural resources, as well as eliminate the poverty of local people by contributing to rural development, is to project local ecotourism activities to benefit from the potentials of the park. Several papers have been published on the subject of ecotourism potential of the area (Vujko et al., 2012; Medić et al., 2012; Počuča \& Matijašević-Obradović, 2017), but with no particular reference to rural development. Thus, to develop ecotourism as an important opportunity for rural development and nature conservation, primarily research for determination of the ecotourism potential and solutions for rural poverty problems of the area is needed.

In order to improve the management of a protected area, it is important to gather information on its status, biodiversity, conservation pattern, tourism potentials, development programs, related problems and overall 
circumstances of the area. The main objective of this study is to identify the factors for the development of ecotourism in the Fruška Gora National Park and to predict possible benefits for strengthening the rural economy of the area. All relevant characteristics of the area, as actual opportunities for the development of ecotourism, are presented in the paper. In addition, by studying the potential ecotourism products of the park, as well as demographic and socio-economic status of the local community, the direct and indirect benefits of ecotourism in the context of strengthening the rural economy will be identified.

\section{Materials and methods}

\section{Study area}

The Fruška Gora National Park is located in the northern part of the Republic of Serbia, within the Autonomous Province of Vojvodina. Established in the year 1960, it is the oldest national park in the country. The park is located between $45^{\circ} 00^{\prime}$ and $45^{\circ} 15^{\prime}$ north latitude and between $16^{\circ} 37^{\prime}$ and $18^{\circ} 01^{\prime}$ 'east longitude, covering an area of 26,672 ha and spreading over eight municipalities and 45 cadastral municipalities. The park is mostly situated on the central massif of Fruška Gora - a low island type mountain range, with a length of about $80 \mathrm{~km}$ in its west-east direction and the highest peak Crveni Čot (539 m a. s. 1.). By its location, the area should have a continental climate, but due to the structure of the mountain, the climate is modified into a sub-continental one. In the geological structure, Paleozoic-Mesozoic formations can be found, such as crystal shale, phyllite, serpentinite, granite, basalt, and limestone (Lazić et al., 2008). The area has 187 springs and 42 streams, while the length of the river network is $437.9 \mathrm{~km}$. The area mainly consists of forest cover $(88.5 \%)$ and has diverse fauna and flora, including numerous rare, relic and endemic species. It also has rich cultural heritage. Thus, three degrees of protection have been established in the area $\left[1^{\text {st }}\right.$ degree of protection 933.3 ha $(3.5 \%)$, $2^{\text {nd }}$ degree of protection $17,737.1$ ha $(66.5 \%)$ and $3^{\text {rd }}$ degree of protection $8,001.6$ ha $(30 \%)$ ] (Figure 1).

\section{Methodology}

The study is a result of an analysis of the ecotourism potential of the Fruška Gora National Park. It aimed to propose the development of ecotourism which would promote sustainable development in the area. In particular, the study was performed to identify and promote the natural and cultural 
values that are potential source of ecotourism, including the settlements located along the buffer zone of the park.

After a comprehensive literature research, ecotourism potential of the area was evaluated via fieldwork and the notes taken at conversations with locals and officials. The study also dealt with written sources available on the Internet. Methods of theoretical analysis and synthesis, geographical and ecological research method and the method of immediate observation were used. Since the ecotourism potentials are defined by the natural, geographical and cultural legacy of the area, the data of tourism potentials that were used in the study included biological potential, physical potential (accessibility, infrastructures and the supporting facilities) and human resources.

No biodiversity assessment method in particular was used, but biodiversity of the area, as described in the paper, was assessed based on literature data, along with personal observations and informal discussions with the officials, local people and visitors. The analysis of type, number and size of protected sites and land use in the area has been done based on literature data (PE Fruška Gora National Park, 2018; The Urban and Spatial Planning Institute of Vojvodina, 2018).

SWOT and PESTEL analyses were also used in the example of the Fruška Gora National Park to become aware of precisely realistic chances of developing sustainable ecotourism in the area. SWOT analysis technique was used to explain current constraints and future possibilities of ecotourism in the national park, while PESTEL analysis gets deeper into the problem of the development of ecotourism in the area.

Given that there are settlements around the park whose people depend on the park and the adjacent land for their livelihood, the study also involved a socio-economic survey based on the official data of the Statistical Office of the Republic of Serbia. Regarding the socio-demographic context, we studied the changes in the population trends, household numbers and average duration of life based on the available census data for the period from 1991 to 2011. Also, based on the census data for 2012, agricultural holding numbers and the size and share of agricultural population were analyzed to estimate the dependency of the local community on natural resources of the area. Data were collected and analyzed for eight municipalities and 45 cadastral municipalities. 
Figure 1: Study area

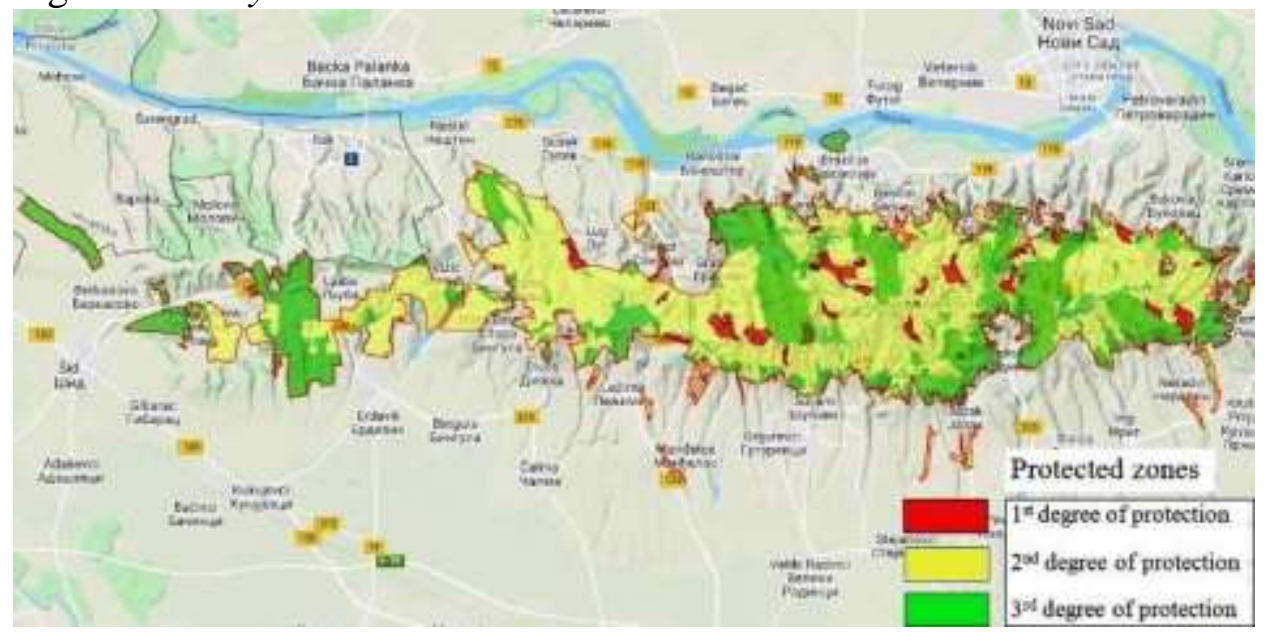

Source: Fruškać, 2020

\section{Results and discussion}

Located only $15 \mathrm{~km}$ from the city of Novi Sad, on the main road Novi SadRuma-Šabac, the Fruška Gora National Park is easily accessible to the potential tourists. It is considered to be an attractive tourist destination because it has many geological and paleontological sites, it is rich in flora and fauna and cultural heritage, and has a well-developed infrastructure of local and forest roads (Table 1). The most prominent geological sites of the park are Grgeteg, Papradine, Grgurevačka Pećina, Orlovac, Šakotinac, Kozje Brdo, and Rakovac (Institute for Nature Conservation of Vojvodina Province, 2020). Six abandoned mine lands have been reclaimed (Stražilovo I and II, Paragovo I and II, Perina Pećina, and Kozje Brdo). Numerous plant and animal species are rare and protected (73 plant species, 38 mammal species, 14 amphibian and reptile species, and more than three insect species) (PE Fruška Gora National Park, 2018). Natural habitats of some species are also under some degree of protection. In the zone of the $1^{\text {st }}$ degree of protection, among these habitats are the following: a protected habitat of endangered plant species Cheilanthes marantae (L.) Domin, habitats of endangered bird species on 13 sites, habitats of endangered insect species on three sites and habitats of important forest ecosystems on 14 sites (Provincial Government, 2015). In the zone of the $2^{\text {nd }}$ degree of protection, there are two protected stands of Alnus glutinosa (L.) Gaertn, and in the zone of the $3^{\text {rd }}$ degree of protection there are protected individual trees or groups (belonging to 11 species) on 16 sites (PE Fruška Gora National Park, 2011). The park is an Important Bird Area (IBA - 011SER) 
and a Prime Butterfly Area (PBA). Among the most important monuments of the cultural heritage in the area, there are eight monasteries (Velika Remeta, Novo Hopovo, Staro Hopovo, Jazak, Mala Remeta, Grgeteg, Beočin, and Vrdnik), and four monasteries that are located in the vicinity of the park (Divša, Petkovica, Kuveždin and Rakovac) (PE Fruška Gora National Park, 2018). All of the above characteristics are a potential for the development of ecotourism in the park, and it is not surprising that the area is already a popular tourist destination for about three million residents of Belgrade, Novi Sad and Sremska Mitrovica and the municipalities located along the buffer zone of the park. Over 400,000 visitors have been expected only in 2018 (Ozon Media, 2018). Specifically, excursions represent the most common tourist activity in the area. The tourists organized in groups or on an individual basis usually visit monasteries and picnic areas (Iriški Venac, Stražilovo, and Zmajevac). There are also some other activities, such as walking in nature, hiking, biking, bird watching, and water-related activities in the summer season. Cultural tourism brings immense potential to this area (Medić et al., 2012). Such tourist activities that should be implemented sustainably not only protect wildlife but also help the survival of the natural area and increase the ecological awareness of people, especially the locals (Boz, 2014). The field survey revealed that the number of tourists visiting the Park was very encouraging and increasing day by day. Still, the current level of tourism neither corresponds to the resources that exist in the area nor meets the requirements of tourist demand.

Protected areas can be very interesting to tourists due to their possession of rare flora and fauna, special habitats and ecosystems (Boz, 2014). In the Fruška Gora National Park, there are more than 40 plant species that are considered rare [e.g., Pulsatilla vulgaris subsp. Grandis (Wender.) Zāmelis, Adonis vernalis L., Sternbergia colchiciflora Waldst. \& Kit.], along with 32 orchid species (Provincial Government, 2015). This potential attracts the attention of special tour groups. The tour activity is organized in an area where there are special habitats, and at a particular time of the year (Boz, 2014). For instance, in late winter and early spring, local tourists are often attracted by the first snowdrops flowering in the area. Snowdrops are believed to be harbingers of spring, and in late winter they are present abundantly in the Fruška Gora National Park, being, in fact, the most abundant population of the common snowdrop (Galanthus nivalis L.) in the country (Jovanović et al., 2016, 2018). The population is a potential of botanical tourism, and it is expected that this kind of tourism, which protects the environment and the prosperity of the local people, could contribute socially and economically to the area. 
Table 1: Characteristics of the National Park important for the development of ecotourism

\begin{tabular}{|c|c|c|}
\hline No. & Characteristic & Description \\
\hline 1. & $\begin{array}{l}\text { Location and } \\
\text { connections }\end{array}$ & $\begin{array}{l}\text { On the roads Novi Sad-Belgrade, Novi Sad-Bačka Palanka-Ilok-Šid, } \\
\text { Novi Sad-Belgrade-Neštin-Ilok, etc. }{ }^{1} \text { Distance from Novi Sad } 15 \mathrm{~km} \text {, and } \\
\text { Belgrade } 50 \mathrm{~km} \text {. In the vicinity of Sremski Karlovci and the Danube }\end{array}$ \\
\hline 2. & Geological sites & \begin{tabular}{|lrllll}
$7 \quad$ geological sites & 2 \\
Grgurevačka Pećina site $^{2}$ & paleontological & sites $(284$ fossil & species $)^{3} ;$
\end{tabular} \\
\hline 3. & $\begin{array}{l}\text { Biodiversity of } \\
\text { species }\end{array}$ & $\begin{array}{l}\text { c. 1,000 plants, c. } 1,750 \text { fungi, } 60 \text { mammals, > } 20 \text { amphibians and reptiles, } \\
>1,700 \text { insects, } 150 \text { birds }^{2,4}\end{array}$ \\
\hline 4. & $\begin{array}{l}\text { Biodiversity of } \\
\text { habitats }\end{array}$ & 5 forest sites, 11 forest-steppe sites, 7 steppe pasture sites, 1 wetland site ${ }^{5}$ \\
\hline 5. & Cultural heritage & 8 monasteries and monuments from World War II ${ }^{2}$ \\
\hline 6. & Road network & $\begin{array}{l}\text { Main road Novi Sad-Ruma-Šabac and other roads, forest roads }(313.7 \mathrm{~km}) \\
\text { and hiking trails }(250 \mathrm{~km})^{1,6}\end{array}$ \\
\hline
\end{tabular}

Source: ${ }^{I}$ The Urban and Spatial Planning Institute of Vojvodina (2018); ${ }^{2}$ PE Fruška Gora N.P. (2018); ${ }^{3}$ Fruškać (2020); ${ }^{4}$ PE Fruška Gora N.P. (2011); ${ }^{5}$ Institute for Nature Conservation of Vojvodina Province (2015); ${ }^{6}$ PE Fruška Gora N.P. (2016-2017)

Given that the study area mainly consists of wooded land, it may be argued that the most important resource of the area is forest vegetation belonging to 23 communities (Table 2). Out of 23 communities recorded in the area, 13 communities were found in the zone of the $1^{\text {st }}$ degree of protection, and 22 communities were found in the zone of the $2^{\text {nd }}$ degree of protection, while 20 communities were found in the zone of the $3^{\text {rd }}$ degree of protection. In the zone of the $1^{\text {st }}$ degree of protection, the most abundant community is a beech-sessile oak forest (ass. Querco-Fagetum) covering 281.1 ha (44.7\% of the park), while the least abundant community, with an area of 7.0 ha (1.1\% of the park), is a Turkey oak forest (ass. Quercetum cerris).

Beech-sessile oak forest is also the most abundant community in the zone of the $2^{\text {nd }}$ degree of protection, with an area of 2,478.0 ha $(20.5 \%$ of the park), while the least abundant community in the same zone is a sessile oak-beech forest (ass. Querco-Fagetum moesiacae montanum) covering $0.3 \mathrm{ha}\left(0.001 \%\right.$ of the park). In the zone of the $3^{\text {rd }}$ degree of protection, the most abundant community is a common oak-hornbeam-Turkey oak-linden forest (ass. Carpino-Quercetum roboris) covering 1,021.2 ha (28.1\% of the park), while the least abundant one, with an area of 0.3 ha $(0.001 \%$ of the park), is the subalpine beech forest (ass. Fagetum moesiacae subalpinum) (Table 2). 
Table 2: Forest communities in the area arranged by degree of protection

\begin{tabular}{|c|c|c|c|c|c|c|c|}
\hline \multirow{2}{*}{ No. } & \multirow{2}{*}{ Community } & \multicolumn{2}{|c|}{$1^{\text {st }}$ degree } & \multicolumn{2}{|c|}{$2^{\text {nd }}$ degree } & \multicolumn{2}{|c|}{$3^{\text {rd }}$ degree } \\
\hline & & ha & $\%$ & ha & $\%$ & ha & $\%$ \\
\hline 1. & White willow forest & & & 7.2 & 0.1 & 10.4 & 0.3 \\
\hline 2. & White willow-European dewberry forest & & & 4.8 & 0.0 & 5.3 & 0.2 \\
\hline 3. & White poplar-black poplar forest & & & 16.1 & 0.1 & 33.2 & 0.9 \\
\hline 4. & Common oak-hornbeam-Turkey oak-linden & & & 1059.9 & 8.8 & 1021.2 & 28.1 \\
\hline 5. & Common oak-hornbeam-Turkey oak-lindens & 16.2 & 2.6 & 969.4 & 8.0 & 698.9 & 19.3 \\
\hline 6. & Oak-hornbeam forest on terrestrial habitats & 17.7 & 2.8 & 292.0 & 2.4 & 266.6 & 7.4 \\
\hline 7. & Oak-hornbeam forest & 27.6 & 4.4 & 1073.2 & 8.9 & 206.5 & 5.7 \\
\hline 8. & Sessile oak-hornbeam-Turkey oak forest & 18.6 & 3.0 & 485.2 & 4.0 & 108.7 & 3.0 \\
\hline 9. & Sessile oak-hornbeam forest & 76.9 & 12.2 & 658.8 & 5.5 & 162.3 & 4.5 \\
\hline 10. & Common oak-mahaleb cherry forest & & & 2.3 & 0.0 & 1.9 & 0.1 \\
\hline 11. & Turkey oak forest & 7.0 & 1.1 & 305.7 & 2.5 & 29.3 & 0.8 \\
\hline 12. & Oak-manna ash forest & 21.7 & 3.5 & 197.2 & 1.6 & 140.2 & 3.9 \\
\hline 13. & Turkey oak-oak of Virgil forest & 37.9 & 6.0 & 1223.8 & 10.1 & 194.0 & 5.4 \\
\hline 14. & Downy oak-oak of Virgil forest & & & 140.5 & 1.2 & 61.6 & 1.7 \\
\hline 15. & Oriental hornbeam-oak forest & 16.4 & 2.6 & 36.7 & 0.3 & 32.4 & 0.9 \\
\hline 16. & Sessile oak-Turkey oak forest & 25.3 & 4.0 & 774.5 & 6.4 & 107.9 & 3.0 \\
\hline 17. & Sessile oak-beech forest & & & 0.3 & 0.0 & & \\
\hline 18. & Sessile oak forest & 52.7 & 8.4 & 2023.0 & 16.7 & 282.4 & 7.8 \\
\hline 19. & Sessile oak forest with moss & & & 2.5 & 0.0 & & 0.0 \\
\hline 20. & Beech-sessile oak forest & 281.1 & 44.7 & 2478.0 & 20.5 & 253.5 & 7.0 \\
\hline 21. & Submontane beech forest & 29.9 & 4.8 & 338.1 & 2.8 & 12.5 & 0.3 \\
\hline 22. & Montane beech forest & & & 8.3 & 0.1 & & \\
\hline 23. & Subalpine beech forest & & & & & 0.3 & 0.0 \\
\hline & Total: & 629.2 & 100.0 & 12097.5 & 100.0 & 3629.0 & 100.0 \\
\hline
\end{tabular}

Source: Authors' research based on literature data (PE Fruška Gora National Park, 2016-2017)

In the zone of the $1^{\text {st }}$ degree of protection, the largest area is occupied by the municipality of Beočin (337.9 ha) having seven cadastral municipalities and the greatest number of sites under protection (14). On the other hand, the smallest area in the zone is occupied by the (cadastral) municipality of Sremski Karlovci (21.5 ha) having only two protected sites (Table 3). Based on the data given in literature (Provincial Government, 2015), the most important protected sites are geological and geomorphological site "Grgurevačka Pećina" (0.9 ha), habitat of endangered plant species (0.9 ha), habitats of endangered bird species on 13 sites (535.3 ha), habitats of endangered insect species on three sites ( $86.4 \mathrm{ha}$ ) and forest ecosystems on 14 sites (309.8 ha). In terms of land use, the park is mostly occupied by forests $(88.5 \%)$ that cover an area of 23,204.4 ha, while $9.9 \%$ is occupied by agricultural land (pastures $5 \%$, arable land $3 \%$, meadows $2 \%$ ) and $0.9 \%$ by built-up land (The Urban and Spatial Planning Institute of Vojvodina, 2018). These categories are predominant in the municipalities of Beočin, Sremska Mitrovica and Irig (Table 4) suggesting high potential for 
ecotourism and rural development, especially because the forest land in these municipalities makes $64.4 \%$ of all forest land in the park.

Table 3: Sites under the $1^{\text {st }}$ degree of protection

\begin{tabular}{|c|c|c|c|c|}
\hline No. & Site & Municipality & $\begin{array}{c}\text { Cadastral } \\
\text { municipality }\end{array}$ & $\begin{array}{c}\text { Area } \\
\text { (ha) }\end{array}$ \\
\hline & Stražilovo, Suvi Potok & Sremski Karlovci & Sremski Karlovci & 21.5 \\
\hline 2. & Rokov Potok - Papradine, Popovica & \multirow[b]{2}{*}{ Petrovaradin } & Srem. Kamenica & 55.2 \\
\hline & $\begin{array}{l}\text { Popovica, Javornati Do, Zmajevac- } \\
\text { Kamenar, Kraljeve Stolice }\end{array}$ & & Ledinci & 84.7 \\
\hline & Kalin Potok, Ignjatov Hrast & \multirow{3}{*}{ Irig } & Grgeteg & 111.2 \\
\hline & Vrbica & & Vrdnik & 2.6 \\
\hline & Srneći Potok - Tatarica, Jazak & & Jazak - Prnjavor & 41.2 \\
\hline & Veliki Gradac, Rakovački Mali Potok & \multirow{7}{*}{ Beočin } & Rakovac & 73.7 \\
\hline & $\begin{array}{l}\text { Čendreviti Čot, Crvene Krečane - Kozarski } \\
\text { Potok, Ravni Breg, Drenovac, Orlovac }\end{array}$ & & Beočin & 71.5 \\
\hline & $\begin{array}{l}\text { Čerevićki Potok - Đerova Kosa, Grabić } \\
\text { (Kestenski Put), Široki Cer, Gradac }\end{array}$ & & Čerević & 127.4 \\
\hline 10. & Biklav & & Sviloš & 0.2 \\
\hline 11. & Ravne & & Grabovo & 3.0 \\
\hline & Janok - Kišelez & & Susek & 1.2 \\
\hline & Janok - Kišelez & & Lug & 60.9 \\
\hline & Ravne & \multirow{5}{*}{$\begin{array}{l}\text { Sremska } \\
\text { Mitrovica }\end{array}$} & Manđelos & 92.6 \\
\hline & Biklav, Ležimir & & Ležimir & 39.8 \\
\hline 16. & Đurđin Grab, Gradac & & Šuljam & 53.0 \\
\hline 17. & Šuljam, Grgurevačka Pećina, Papratski Do & & Grgurevci & 87.8 \\
\hline & Kraljevac & & Bešenovo & 6.1 \\
\hline & Total: & 5 & 18 & 933.6 \\
\hline
\end{tabular}

Source: Authors' research based on literature data (Provincial Government, 2015; PE Fruška Gora National Park, 2018)

The dynamics of social and demographic indicators of rural development are determined for the eight municipalities and 45 cadastral municipalities that constitute the area (Table 5). The results show that the population of the area raised between 1991 and 2002, while between 2002 and 2011 it declined in all municipalities except in Petrovaradin. The share of the population under 15 years of age has been constantly declining, while the share of the population over 65 years raised in all municipalities except in Sid. The average size of a household is decreasing in the area. According to the latest census, the average size of a household is 2.8. Similar negative social and demographic trends (population decline, migrations, changes in age structure, etc.) have been also detected in our research for the southern (Braunović \& Perović, 2017) and eastern parts of Serbia (Braunović \& Ratknić, 2018). These trends, along with poor economic conditions and insufficient financial support by the State, are the most important factors that constrain rural development. On the other hand, the share of the 
population in active working-age slightly raised in most of the municipalities except in Beočin, Bačka Palanka, and Petrovaradin.

Table 4: Land use in the area of the National Park

\begin{tabular}{|c|c|c|c|c|c|c|c|c|c|c|}
\hline \multirow{3}{*}{ Land use } & \multicolumn{10}{|c|}{ Area of the National Park } \\
\hline & \multicolumn{8}{|c|}{ Municipality } & \multicolumn{2}{|c|}{ Total } \\
\hline & \begin{tabular}{|c|} 
Bačka \\
Palanka
\end{tabular} & Beočin & Inđija & Irig & \begin{tabular}{|c|} 
Petro- \\
varadin
\end{tabular} & \begin{tabular}{c|} 
Srem. \\
Karl.
\end{tabular} & $\begin{array}{l}\text { Srem. } \\
\text { Mitr. }\end{array}$ & Šid & ha & $\%$ \\
\hline Agricultural & 92.6 & 928.1 & 6.8 & 503.8 & 297.2 & 92.9 & 516.2 & 192.8 & 2630.2 & 9.9 \\
\hline Other land & 92.6 & 928.1 & 6.8 & 503.8 & 297.2 & 92.9 & 516.2 & 192.8 & 2584.4 & \\
\hline Tourist-recreat. & & & & 1.1 & 44.8 & & & & 45.8 & \\
\hline Forest land & 1122.7 & 6177.6 & 234.1 & 4145.5 & 2479.8 & 558.5 & 4822.1 & 4037.2 & 23577.5 & 88.5 \\
\hline $\begin{array}{l}\text { Forests and } \\
\text { wooded land }\end{array}$ & 1115.2 & 6157.0 & 158.6 & 4088.4 & 2382.1 & 552.7 & 4814.7 & 393.7 & 23204.4 & \\
\hline Monumental & & & & 1.3 & & & 1.0 & & 2.3 & \\
\hline Orchards & & 2.1 & & & & & & & 2.1 & \\
\hline Tourist-recreat. & 7.4 & 17.6 & 75.5 & 55.8 & 97.7 & 5.8 & 6.4 & 102.4 & 368.6 & \\
\hline Water & 0.2 & 129.0 & & 14.8 & 21.7 & 2.0 & 16.6 & 23.5 & 207.7 & 0.8 \\
\hline Danube River & - & 39.1 & & - & - & - & - & - & 39.1 & \\
\hline $\begin{array}{l}\text { Lakes and } \\
\text { swamps }\end{array}$ & & & & & 9.6 & - & & & 9.6 & \\
\hline Reservoirs & - & & & - & & - & & 21.7 & 21.7 & \\
\hline $\begin{array}{l}\text { Stagnant flood } \\
\text { water }\end{array}$ & - & 36.2 & & & & 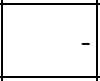 & & & 36.2 & \\
\hline $\begin{array}{l}\text { Streams and } \\
\text { canals }\end{array}$ & 0.2 & 39.9 & & 14.8 & 12.1 & 2.0 & 16.6 & 1.8 & 87.4 & \\
\hline $\begin{array}{l}\text { Forested } \\
\text { wetlands }\end{array}$ & & 13.9 & & & & & & & 13.9 & \\
\hline Built-up land & 1.2 & 42.9 & 21.8 & 81.6 & 32.3 & 6.2 & 37.0 & 15.6 & 238.5 & 0.9 \\
\hline Residential & - & - & & 5.8 & 3.6 & - & 3.0 & - & 12.3 & \\
\hline Monastaries & & 1.8 & & 6.1 & & - & 0.6 & & 8.5 & \\
\hline Tourist-recreat. & & 9.9 & & 14.8 & 5.7 & - & 8.3 & 0.6 & 39.3 & \\
\hline $\begin{array}{l}\text { Commercial } \\
\text { and services }\end{array}$ & & & & 16.6 & & & & & 16.6 & \\
\hline $\begin{array}{l}\text { Infrastracture } \\
\text { complex }\end{array}$ & & 1.7 & & 1.9 & 0.3 & & & & 3.9 & \\
\hline $\begin{array}{l}\text { Infrastructure } \\
\text { land }\end{array}$ & 1.2 & 29.5 & 21.8 & 36.4 & 22.8 & 6.2 & 25.2 & 15.0 & 157.9 & \\
\hline \begin{tabular}{|l} 
Total \\
\end{tabular} & 1216.6 & 7277.6 & 262.6 & 4745.6 & 2830.9 & 659.6 & 5392.0 & 4269.0 & 26653.9 & \\
\hline$\%$ & 4.6 & 27.3 & 1.0 & 17.8 & 10.6 & 2.5 & 20.3 & 16.0 & 100.0 & \\
\hline
\end{tabular}

Source: The Urban and Spatial Planning Institute of Vojvodina (2018)

The share of the population in active working-age makes $68.1 \%$ of the total population and the average duration of life is 44.2 years. Moreover, the results of the study highlight park-people relationships and the dependency of the locals on resources of the area, considering that the share of the agricultural population is $13.2 \%$ and the number of agricultural holdings is 8991. These factors, along with biodiversity of flora and fauna and rich cultural heritage of the park, are potentials for the rural development based 
on sustainable ecotourism, given that the basic function of ecotourism is not only a preservation of natural areas but also income gain, education, and participation of the locals (Lutovac \& Đuričić, 2014). The impact of ecotourism on an area manifests itself through the decrease of unemployment, the improvement of the demographic situation in the area, the development and strengthening of the local economy and thus reduces the disparities in the development of the area (Rokvić et al., 2017).

Even though a national park is a good instrument for biodiversity conservation, ignoring the dependency of local people on park resources creates conflicts between local communities and the park authority (Nath \& Alauddin, 2006). Protected areas as means of biodiversity conservation and national development could be justified only if they contribute to the well-being of local people (Robinson \& Ginsberg, 2004).

Some activities should be established to reduce the dependency of the locals on natural resources of the area (Nath \& Alauddin, 2006). For instance, the locals could benefit financially by providing accommodations and catering services to the tourists. Similarly, should educated persons be involved, they can act as tourist guides.

The Fruška Gora National Park is currently at the initial stage of ecotourism development and it is hoped that it will incorporate local participation for better conservation of biodiversity and well-being of the local community. According to literature data, out of the 57 settlements in the area, 46 have up to 3,000 inhabitants and agriculture is the most important economic sector for the majority of them. It was stated that most of the area has a predominantly rural character and most of the actual activities already take place in a rural area (Medić et al., 2012). On the other hand, only the parallel development of the non-agricultural sector can increase rural employment chances, improve the quality of life of a rural population, provide them with alternative sources of income and preserve rural communities (Erokhin, 2011).

From the discussion above, it is clear that the contribution of ecotourism to the restructuring of weak economies is unquestionable. The most important expected effects of ecotourism development are increasing the degree of involvement of the rural population in new employment opportunities, improving the quality of rural life, rural area development, and the growth of the economy of the area (Ivolga \& Molchanenko, 2014). 
Table 5: Dynamics of socio-demographic indicators of rural development in 1991-2012

\begin{tabular}{|c|c|c|c|c|c|c|c|c|c|c|}
\hline \multirow[b]{2}{*}{ Indicators } & \multirow[b]{2}{*}{ Year } & \multicolumn{8}{|c|}{ Municipality } & \multirow[b]{2}{*}{ Total } \\
\hline & & Beočin & Šid & \begin{tabular}{|c|} 
Bačka \\
Palanka
\end{tabular} & \begin{tabular}{|c|} 
Srem. \\
Mitrov.
\end{tabular} & Irig & $\begin{array}{c}\text { Petro- } \\
\text { varadin }\end{array}$ & \begin{tabular}{|l|} 
Srem. \\
Karlov.
\end{tabular} & Inđija & \\
\hline \multirow{3}{*}{$\begin{array}{l}\text { Average size } \\
\text { of a settlement, } \\
\text { person }\end{array}$} & \begin{tabular}{|l|l|}
1991 \\
\end{tabular} & 14848 & 21893 & 1394 & \begin{tabular}{|l|l|}
7894 \\
\end{tabular} & 10308 & 23560 & 7534 & 32356 & 119787 \\
\hline & 2002 & 16086 & 23966 & 1249 & 7941 & 10869 & 30404 & 8839 & 37166 & 136520 \\
\hline & \begin{tabular}{|l|l|}
2011 \\
\end{tabular} & 15726 & 21251 & 1064 & 6652 & \begin{tabular}{|l|}
9532 \\
\end{tabular} & 32931 & 8750 & 35853 & 131759 \\
\hline \multirow{3}{*}{$\begin{array}{l}\text { Population under } \\
15 \text { years, } \%\end{array}$} & \begin{tabular}{|l|}
1991 \\
\end{tabular} & 18.5 & \begin{tabular}{|l|}
16.6 \\
\end{tabular} & 16.6 & $\begin{array}{l}16.3 \\
\end{array}$ & 15.4 & 23.7 & 20.0 & \begin{tabular}{|l|}
19.2 \\
\end{tabular} & 18.3 \\
\hline & 2002 & 17.8 & 15.6 & 13.6 & 15.6 & 13.0 & 16.6 & 15.2 & 15.4 & 15.3 \\
\hline & 2011 & \begin{tabular}{|l|}
13.7 \\
\end{tabular} & 13.6 & 12.3 & $\begin{array}{l}9.3 \\
\end{array}$ & 9.4 & 14.5 & 13.8 & 11.9 & 12.31 \\
\hline \multirow{3}{*}{$\begin{array}{l}\text { Population over } \\
65 \text { years, } \%\end{array}$} & 1991 & 11.5 & 15.8 & 12.1 & \begin{tabular}{|l|}
13.3 \\
\end{tabular} & 16.1 & 8.9 & 11.7 & 12.5 & 12.7 \\
\hline & 2002 & 16.5 & 19.9 & 21.6 & 15.0 & 22.6 & \begin{tabular}{|l|}
12.7 \\
\end{tabular} & 15.5 & 18.1 & 17.7 \\
\hline & \begin{tabular}{|l|}
2011 \\
\end{tabular} & 18.1 & 18.9 & 24.3 & 20.4 & 24.2 & 15.1 & 15.7 & 20.0 & 19.60 \\
\hline \multirow{3}{*}{$\begin{array}{l}\text { Population in } \\
\text { working age, \% }\end{array}$} & \begin{tabular}{|l|l|}
1991 \\
\end{tabular} & 68.4 & 67.6 & 71.3 & 70.4 & 68.5 & \begin{tabular}{|l|}
67.4 \\
\end{tabular} & 68.3 & 68.4 & 68.8 \\
\hline & 2002 & 68.3 & 64.5 & 64.8 & \begin{tabular}{|l|}
69.4 \\
\end{tabular} & 64.4 & 70.7 & 69.3 & 66.6 & 67.2 \\
\hline & 2011 & 68.2 & 67.5 & 63.4 & 70.3 & 66.4 & 70.4 & 70.5 & 68.1 & 68.1 \\
\hline \multirow{3}{*}{$\begin{array}{l}\text { Average size of a } \\
\text { household, person }\end{array}$} & \begin{tabular}{|l|l|}
1991 \\
\end{tabular} & 3.0 & 2.9 & 3.1 & 3.1 & 2.8 & 3.0 & 3.0 & 2.7 & 2.9 \\
\hline & 2002 & 2.9 & 3.0 & 2.4 & 2.9 & 2.8 & 3.0 & 3.0 & 3.0 & 2.9 \\
\hline & \begin{tabular}{|l|}
2011 \\
\end{tabular} & 2.8 & 2.7 & 2.6 & 2.8 & 2.7 & 3.0 & 2.9 & 2.9 & 2.8 \\
\hline \multirow{3}{*}{$\begin{array}{l}\text { Average duration } \\
\text { of life, years }\end{array}$} & 1991 & & & & & & & & & \\
\hline & 2002 & 39.4 & 41.7 & 43.3 & 41.4 & 44.4 & \begin{tabular}{|l|}
38.3 \\
\end{tabular} & 39.8 & 41.1 & 41.2 \\
\hline & \begin{tabular}{|l|}
2011 \\
\end{tabular} & 42.6 & 43.6 & 46.2 & 46.0 & 47.5 & 41.2 & 42.2 & 44.4 & 44.2 \\
\hline $\begin{array}{l}\text { Number of } \\
\text { agricult. holdings }\end{array}$ & \multirow{3}{*}{2012} & 1068 & 2087 & 194 & 1580 & 1188 & 798 & 267 & 1809 & 8991 \\
\hline \begin{tabular}{|l|} 
Agricultural \\
population, person
\end{tabular} & & 2013 & 3920 & 443 & 3037 & 2330 & 1311 & 507 & 3823 & 17384 \\
\hline $\begin{array}{l}\text { Agricultural } \\
\text { population, \% }\end{array}$ & & 12.8 & 18.4 & 41.6 & 45.7 & 24.4 & 4.0 & 5.8 & 10.7 & 13.2 \\
\hline
\end{tabular}

Source: Statistical Office of the Republic of Serbia (2011, 2012, 2014a, 2014b)

Based on the results of the SWOT (Table 6) and PESTEL analyses (Table 7), the most important advantages and opportunities for the development of ecotourism in the Park are large areas in the protected zones, numerous touristic facilities (educational trails, eco-camp, mountain lodges), nature conservation (ecological projects, nature conservation movements, NGOs, ranger service), raising awareness of the local community about the environment, involvement of young and educated people, ecotourism benefits for the local community, well-connected road networks, and establishment of buffer zone around the park.

On the other hand, the main disadvantages, weaknesses, and threats to ecotourism and rural development of the area are insufficient investments and incentives of the State, lack of initiative and disregard for the importance of ecotourism for the development of the area, absence of GIS database (mapping of trails and sites of protected species, etc.), weak institutional cooperation, absence of a common strategy on tourism 
development and management of the Park, youth migration, inconsistent and insufficient promotion of the destination, undeveloped economy, insufficient relationship between the Park management and the local people, and unsatisfying involvement of the local people.

\section{Table 6: SWOT analysis of the ecoutourism in the National Park}

\begin{tabular}{|c|c|}
\hline & \\
\hline $\begin{array}{l}\text { - Implementation of strategy on sustainable } \\
\text { management of habitats, species and cultural } \\
\text { heritage (until 2027); } \\
\text { - International projects; } \\
\text { - Workshops with the local community to raise } \\
\text { awareness about natural resources; } \\
\text { - Information center on Iriški Venac; } \\
\text { - Implementation of the management plan on } \\
\text { the Park visiting, and better-equiped ranger } \\
\text { service; } \\
\text { - Improved communication, education and } \\
\text { participation of the local people; } \\
\text { - Nature Conservation Movement "Defend the } \\
\text { forests of Fruška Gora"; } \\
\text { - Online guide to the Fruška Gora National } \\
\text { Park (Fruskac.net); } \\
\text { - The interest of the local community in } \\
\text { tourism development (a possible driver of } \\
\text { rural development); } \\
\text { - Establishing a buffer zone along the Park. }\end{array}$ & $\begin{array}{l}\text { - Lack of cooperation among institutions, local } \\
\text { self-governments, non-governmental sector, } \\
\text { local community and others in the } \\
\text { implementation of strategic and planning } \\
\text { documents; } \\
\text { - Failure to recognize the value of the Park and } \\
\text { the need to protect the area; } \\
\text { - Lack of education; } \\
\text { - Poor economic conditions; } \\
\text { - Lack of technical and administrative } \\
\text { personnel in the Park and its limited } \\
\text { management capacity due to insufficient } \\
\text { budget; } \\
\text { - Endangerment by surface mines, landfills, } \\
\text { illegal construction, traffic, collection of wild } \\
\text { plants and fungi, hunting, grazing, illegal } \\
\text { logging, fires and torrents; } \\
\text { - Depopulation in some rural areas; } \\
\text { - Mass tourism; } \\
\text { - The danger of damaging the plant and animal } \\
\text { habitats. }\end{array}$ \\
\hline
\end{tabular}

Source: Authors' research 
Table 7: PESTEL analysis of the ecoutourism in the National Park

\begin{tabular}{|c|c|c|}
\hline Factors & Advantages & Disadvantages \\
\hline Political & $\begin{array}{l}\text { - Importance of tourism for the } \\
\text { economic development of Serbia; } \\
\text { - Importance of ecotourism for the local } \\
\text { community; } \\
\text { - EU funds for nature conservation. }\end{array}$ & $\begin{array}{l}\text { - Inadequate budget planning; } \\
\text { - Insufficient investment in } \\
\text { ecotourism; } \\
\text { - Inadequate work of the } \\
\text { responsible ministries. }\end{array}$ \\
\hline Economic & $\begin{array}{l}\text { - } \begin{array}{l}\text { Experts in economy, tourism and hotel } \\
\text { industry; } \\
\text { - Potential for rural tourism } \\
\text { development. }\end{array} \\
\end{array}$ & $\begin{array}{l}\text { - Low State investments in } \\
\text { tourism development; } \\
\text { - Undeveloped economy and } \\
\text { unemployment. }\end{array}$ \\
\hline Social & $\begin{array}{l}\text { - The motivation of the rural population } \\
\text { to work in tourism; } \\
\text { - Young people's interest in ecotourism; } \\
\text { - The high share of the working } \\
\text { population. }\end{array}$ & $\begin{array}{l}\text { - Youth migration from rural } \\
\text { areas; } \\
\text { - Passivity in the development; } \\
\text { - Public and local involvement. }\end{array}$ \\
\hline $\begin{array}{l}\text { Technical } \\
\text { and technological }\end{array}$ & $\begin{array}{l}\text { - Pan-European Corridor X and well- } \\
\text { connected road networks; } \\
\text { - Technological innovations; } \\
\text { - The increasing number of young } \\
\text { people educated in the field of IT. }\end{array}$ & $\begin{array}{l}\text { - Absence of database (mapped } \\
\text { trails and sites, cadastres of } \\
\text { springs and watercourses, etc.); } \\
\text { - No encouraging of research; } \\
\text { - Inconsistent and insufficient } \\
\text { promotion of the destination. }\end{array}$ \\
\hline $\begin{array}{l}\text { Environmental } \\
\text { protection }\end{array}$ & $\begin{array}{l}\text { - A large number of protected plant and } \\
\text { animal species; } \\
\text { - Young people's interest in } \\
\text { environmental protection and their } \\
\text { involvement in the actions; } \\
\text { - Nature conservation actions and eco- } \\
\text { camp. }\end{array}$ & $\begin{array}{l}\text { - Insufficient protection of natural } \\
\text { and cultural values; } \\
\text { - Unacceptable environmental } \\
\text { degradation; } \\
\text { - No monitoring of rare species; } \\
\text { - Insufficient data on } \\
\text { allochthonous flora and fauna. }\end{array}$ \\
\hline Legal aspects & $\begin{array}{l}\text { - Law on Tourism; } \\
\text { - Law on Local Self-Government; } \\
\text { - Nature Conservation Law; } \\
\text { - Environmental Law; } \\
\text { - } \\
\text { Law on Ratification of the Convention } \\
\text { on Biological Diversity. }\end{array}$ & $\begin{array}{l}\text { - Insufficiently stringent } \\
\text { environmental laws; } \\
\text { - Lack of monitoring of } \\
\text { environmental law enforcement } \\
\text { and implementation of } \\
\text { conventions. }\end{array}$ \\
\hline
\end{tabular}

Source: Authors' research

\section{Conclusions}

The convenient location, substantial wildlife resources, abundance in water and geological elements, and the richness of the cultural-historical monuments of the Fruška Gora N.P. exemplify an important ecotourism potential of the area and economic opportunity for the local community. The area mainly consists of wooded land, which is the most important natural resource of the area, suggesting high potential for ecotourism and 
rural development. Thus, we believe in the priority of development of ecotourism as one of the most prospective tools for the attraction of additional income in the area and its sustainable economic development.

Negative socio-demographic trends are the most important factors that constrain rural development of the area. On the other hand, the potential for the rural development of the area based on sustainable ecotourism lies in the fact that the share of the population in working-age slightly raised in most of the municipalities and it makes $68.1 \%$ of the total population, and the average duration of life is 44.2 years. The biggest advantages and opportunities for the development of ecotourism in the area are large protected zones, touristic facilities, raising ecological awareness of the local community, involvement of young people, ecotourism benefits for the local community, and establishment of buffer zone around the Park. The main disadvantages, weaknesses, and threats to ecotourism and rural development in the area are insufficient investments of the State, disregard for the importance of ecotourism, absence of GIS database, weak institutional cooperation, absence of a common strategy on tourism development and Park management, undeveloped economy and poor relationship between the Park management and the local community.

A priority condition for the development of ecotourism in the area is the strong strategic and financial support, which should create the necessary conditions for rural development. One of the goals of future projects should be the promotion of ecotourism as an opportunity that will help rural development. These projects should involve active contribution to the conservation of the natural and cultural heritage of the area, informing visitors on tourist products and contribution to the wealth of local people by their inclusion in planning and development of the area.

\section{References}

1. Boz, D. (2014). Diversification of Botanic Tourism by Benefiting from the Plant-Bioinformatics System. Global Review of Research in Tourism, Hospitality and Leisure Management, 1(2), 102-116.

2. Braunović, S., Perović, V. (2017). Soil Erosion, Changes of Land Use and Migration Trends - Impact on Tourism Development. TISC - Tourism International Scientific Conference, Vrnjačka Banja, 2(2), 306-323.

3. Braunović, S., Ratknić, M. (2018). Migration Trends and the Concept of 
Ecotourism. TISC - Tourism International Scientific Conference, Vrnjačka Banja, 3(2), 750-767.

4. Erokhin, V. L. (2011). Specifics of agricultural entrepreneurship in the conditions of trade and economic integration. Agricultural Bulletin of Stavropol Region, 1(1), 69-72.

5. Fruškać, (2020), https://fruskac.net/, (27 February 2020).

6. Gajić, M., Cvetanović, M. (2015). Theoretical bases of ecotourism and examples of potential ecotourism destinations in Serbia. Bulletin of the Serbian Geographical Society, 95(3), 37-58.

7. Institute for Nature Conservation of Vojvodina Province, (2015), NP "Fruška gora" - Predlog za uspostavljanje zaštite prirodnih vrednosti, u postupku izrade Zakona o nacionalnim parkovima, Novi Sad.

8. Institute for Nature Conservation of Vojvodina Province, (2020), Geonasleđe Fruške gore, http://www.pzzp.rs/rs/sr/zastita-prirode/zastitageonasleda/geonaslede-fruske-gore.html, (07 February 2020).

9. International Union for Conservation of Nature, (IUCN). https://www.iucn.org/, (18 February 2020).

10. Ivolga, A. G., Molchanenko, S. A. (2014). Increase of employment and income of rural population as a factor of sustainable development of regional recreational sector. International Scientific Conference: "Sustainable agriculture and rural development in terms of the Republic of Serbia strategic goals realization within the Danube region: Rural development and (un)limited resources", Belgrade, 18-33.

11. Jovanović, F., Obratov-Petković, D., Bjedov, I., Živanović, I., Braunović, S., Ćirković-Mitrović, T., Tomović, G. (2018). Morphological variability of snowdrops in the central part of the Balkan Peninsula. Hortscience, 53(8), 1119-1124.

12. Jovanović, F., Obratov-Petković, D., Niketić, M., Vukojičić, S. (2016). Distribution of the genus Galanthus L. (Amaryllidaceae) in Serbia. Botanica Serbica, 40(1), 69-81.

13. Lazić, L., Pavić, D., Stojanović, V., Tomić, P. et al. (2008). Protected 
natural assets and ecotourism in Vojvodina, Faculty of Sciences, Department of Geography, Tourism and Hotel Management, Novi Sad.

14. Lutovac, M., Đuričić, M. M. (2014). Ecotourism - An important development opportunity for the Western Balcans and Serbia. First International Conference: "Higher Education in Function of Sustainable Development of Tourism in Serbia and Western Balkans", Užice, 271-282.

15. Medić, S., Gagić, S., Jovičić, A., Erdeji, I. (2012). Possibilities for Improvement of Rural Tourism in Fruška Gora. Journal of Settlements and Spatial Planning, 1, 167-175.

16. Nath, T. K., Alauddin, M. (2006). Sitakunda Botanical Garden and Ecopark, Chittagong, Bangladesh: Its impacts on a rural community. The International Journal of Biodiversity Science and Management, 2, 1-11.

17. Ozon Media, Počinje naplata ulaska u Nacionalni park Fruška gora, http://www.ozon.rs/vestisrbija/2018/pocinje-naplata-ulaska-u-nacionalnipark-fruska-gora/, (28 February 2020).

18. PE Fruška Gora N.P, (2011), Plan upravljanja 2011-2020, Novi Sad.

19. PE Fruška Gora N.P, (2016-2017), Osnove gazdovanja šumama za GJ 3801-3813, Banja Luka.

20. PE Fruška Gora N.P, (2018), Plan upravljanja 2018-2027, Novi Sad.

21. Počuča, M., Matijašević-Obradović, J. (2017). Ecologically important areas and protected natural sites as important potential for the development of ecotourism in Serbia. International Scientific Conference ITEMA 2017, Budapest, 183-192.

22. Provincial Government, (2015), Plan razvoja šuma u nacionalnom parku Fruška gora (2015-2024), Vol. 1, Begrade.

23. Robinson, J. G., Ginsberg, J. R. (2004). Issues in international conservation: Parks, people, and pipelines. Cons. Biology, 18, 607-608.

24. Rokvić, G., Galić, M., Vasko, Ž. (2017). Rural tourism as a means for strengthening rural economy. International scientific conference ITEMA 2017, Budapest, Hungary, 158-166. 
25. Sathe, S., Manipatil, U. R. (2013). Studies on ecotourism potential of Sangli district: Case analysis with reference to places of botanical interest. Review of Research, 2(5), 1-3.

26. Statistical Office of the Republic of Serbia, (2012), Census of Agriculture 2012, Census results by settlements, Belgrade.

27. Statistical Office of the Republic of Serbia, (2014a). Book 20: Comparative Overview of the Number of Population by 1948, 1953, 1961, 1971, 1981, 1991, 2002 and 2011, Censuses - data by settlements, Belgrade.

28. Statistical Office of the Republic of Serbia, (2014b), Book 21: Comparative Overview of the Number of Households by 1948-2011, Censuses and Dwellings by 1971-2011 Censuses, Belgrade.

29. Statistical Office of the Republic of Serbia, (2020), Population by age and sex, by settlements, https://www.stat.gov.rs/ en-US/oblasti/popis/popis-2011/popisni-podaci-eksel-tabele, (15 January 2020).

30. The Urban and Spatial Planning Institute of Vojvodina, (2018), Prostorni plan područja posebne namene Fruška Gora. Novi Sad.

31. Vujko, A., Gajić, T., Kovačević, B. (2012). Turizam u zaštićenim prirodnim prostorima - Ekoturizam Fruške gore. Škola biznisa, (4), 8-16. 